\title{
Oral infections and orofacial pain in Alzheimer's disease Case report and review
}

\author{
Silvia Regina Dowgan T. de Siqueira', Thaís de Souza Rolim², Manoel Jacobsen Teixeira ${ }^{3}$, \\ Ricardo Nitrinit, Renato Anghinah ${ }^{5}$, José Tadeu T. de Siqueira ${ }^{6}$
}

\begin{abstract}
Dental infections, frequent in the general population, are a common cause of inflammation with systemic impact, and are the most common cause of orofacial pain. Temporomandibular disorders are also frequent in the elderly and represent an important cause of secondary headache. Both inflammation and pain can also contribute to cognitive, functional and behavioral impairment of the elderly and aggravate symptoms of patients with Alzheimer's disease (AD). We report a case of a 74-year-old woman with AD and chronic facial pain who had a significant improvement in functional activities as well as in cognition and depressive symptoms after successful treatment of her facial pain. Patients with AD have higher compromise of oral health with infections and teeth loss. The investigation of orofacial pain should be performed in patients with AD, because of the associations reviewed and given the potential for improvement as highlighted by this case.
\end{abstract}

Key words: Alzheimer's disease, elderly, dementia, temporomandibular disorder, orofacial pain.

\begin{abstract}
Infecção oral e dor orofacial na doença de Alzheimer: relato de caso e revisão
Resumo - Infecções dentárias, frequentes na população e geral, são uma causa comum de inflamação com impacto sistêmico e a causa mais comum de dor orofacial. Disfunções temporomandibulares também são prevalentes nos idosos, causam cefaléia secundária. Tanto a dor quanto a inflamação podem também contribuir com o comprometimento cognitivo, funcional e comportamental em idosos e agravar sintomas em pacientes com doença de Alzheimer (DA). Este é um relato de um caso de uma mulher com 74 anos de idade com DA e dor orofacial crônica que apresentou uma melhora significante nas atividades funcionais assim como na cognição e sintomas depressivos depois do tratamento da dor facial. Pacientes com DA tem alto comprometimento da saúde oral com infecções e perdas dentárias. A investigação da dor orofacial deveria ser realizada em pacientes com DA devido às associações revisadas e à possibilidade de melhora como destacadas por este relato.

Palavras-chaves: doença de Alzheimer, idoso, demência, disfunção temporomandibular, dor orofacial.
\end{abstract}

The aging process, or senescence, is characterized by gradual reduction in the functional reserve of the body, a phenomenon which compromises the ability to adapt to external and internal changes but is not an illness state. ${ }^{1,2}$ The elderly can be classified into three groups according to their general state of health: healthy ( $60 \%$ to $75 \%$ of elder- ly), chronically ill (20\% to $35 \%)$ and fragile ( $2 \%$ to $10 \%){ }^{1}$ Among diverse symptoms that this group reports, pain can and must be evaluated as a potential sign of disease. ${ }^{1}$ Many elderly are edentulous, and oral infections are common in the adult population. At these ages, neurodegenerative diseases are also common, of which Alzheimer's disease

${ }^{1}$ DDS, PhD, Assistant Professor, Gerontology, School of Arts, Sciences and Humanities, University of São Paulo, São Paulo SP, Brazil. ${ }^{2}$ DDS, Postgraduate Student, Member of the Orofacial Team, Hospital das Clínicas, Medical School, University of São Paulo, São Paulo SP, Brazil. ${ }^{3} \mathrm{MD}$, PhD, Chairman of Neurosurgery, Neurology Department, Medical School, University of São Paulo, São Paulo SP, Brazil. ${ }^{4}$ MD, PhD, Associate Professor, Head of Group of Cognitive and Behavioral Medicine, Neurology Department, Hospital das Clínicas, Medical School, University of São Paulo, São Paulo SP, Brazil. ${ }^{5}$ MD, Group of Cognitive and Behavioral Medicine, Neurology Department, Hospital das Clínicas, Medical School, University of São Paulo, São Paulo SP, Brazil. ${ }^{6}$ DDS, PhD, Head of the Orofacial Pain Team, Dentistry Division, Medical School, University of São Paulo, São Paulo SP, Brazil.

Silvia Regina Dowgan T. de Siqueira - Rua Carlos Weber 1319 / apto P164 - 05303-000 São Paulo SP - Brazil. E-mail: silviadowgan@hotmail.com Disclosure: The authors report no conflict of interest. 
(AD) is the most prevalent. ${ }^{3,4}$ The objective of this article was to present a case and review the role of oral infections and orofacial pain in AD. Articles published between 1984 and 2008 were searched according to the following keywords: Alzheimer's disease OR elderly OR dementia AND orofacial pain OR oral infections. A case reported in the literature is described below.

\section{Case report}

A woman aged 74 years, diagnosed with mild to moderate $\mathrm{AD}^{5}$ an MMSE (Mini Mental State Exam) ${ }^{6}$ score of 18 , and presenting severe functional impairment identified by a score of 30 on the Functional Activity Questionnaire (scores above 5 are indicative of functional impairment in dementia $)^{7}$ had a complaint of left pre-auricular pain which spread to the head. The pain was throbbing and unbearable, with long crises (hours to days) 2-3 times a week, and had started 3 years earlier but had worsened in the last 10 months. She had little relief with common analgesics. She was completely edentulous but only using the superior prosthesis. Her masticatory muscles (temporalis, masseter and neck muscles) were painful on palpation on both sides. A dental exam was performed using the DMFT (decays, extractions and fillings), the OHIP (45) (assessing quality of life associated to oral health), and the Research Diagnostic Criteria for Temporomandibular Disorders (RDC/TMD) Axis I and II for musculoskeletal diagnosis of the mastica- tory system and psychosocial aspects involved (depression, anxiety and limitations in quality of life).

The proposed initial treatment was 4 applications of TENS (transcutaneous electric neural stimulation) to the masseter muscles, hot water compresses on the face and neck, and physiotherapeutic mouthwashes with $2 \%$ phenol water, three times a day. After 3 weeks, her pain had been alleviated and there was a marked improvement in the FAQ score, as well as in the MMSE and depressive symptoms (Table 1). She was referred for prosthesis treatment at the clinic, which was completed within 3 months. In the follow-up evaluation, she reported no pain or mandibular limitations.

\section{Facial pain in the elderly}

Pain was defined by the International Association for the Study of Pain (1986), as a sensorial and emotional unpleasant experience, associated to a real or potential tissue injury, or described in such terms. ${ }^{8}$ The denomination Orofacial Pain includes all painful conditions of the mouth and face, which are specific to dentistry, and including temporomandibular disorders (TMD) ${ }^{8}$ It s important to note that this is one of the areas of the whole body with the most types of diagnosis, often overlapping, and with significant psychological and social impact. ${ }^{8,9}$ Chronic pain in the community varies from $7 \%$ to $40 \%$, and is persistent in $8 \%$ of individuals. In general, the most common cause is musculoskeletal, often diffuse. ${ }^{10}$

Table 1. Cognitive, behavioral, functional, and mandibular characteristics of the patient before and after treatment.

\begin{tabular}{lcc}
\hline & $\mathbf{1}^{\text {st }}$ Evaluation & 2 $^{\text {nd }}$ Evaluation (after 3 weeks) \\
\hline Pain (Visual Analogic Scale) & 10 & 5 \\
MMSE & 18 & 21 \\
FAQ & 30 & 11 \\
DMFT & 32 & 32 \\
OHIP14** & 23.1 & \\
Severe & 8.5 & \\
Good & & No diagnosis \\
RDC/TMD Axis I & Myofacial pain without mouth & \\
& opening limitation & 1.0 \\
RDC/TMD Axis II & 2.5 & Severe \\
Anxiety & Severe & 0.85 \\
RDC/TMD Axis II & 1.5 & Moderate \\
Depression & Severe & $0 \%$ \\
RDC/TMD Axis II & $58 \%$ & \\
Jaw limitations & & \\
\hline
\end{tabular}

MMSE, Mini Mental State Examination; FAQ, Functional Activities Questionnaire; DMFT, Number of decayed, missing and filled teeth; OHIP 14, Oral Health Impact Profile. ${ }^{45}$ RDC/TMD Axis I and Axis II: Research Diagnostic Criteria for Temporomandibular Disorders, Axis I (clinical evaluation and TMD classification) and Axis II (psychosocial evaluation). 
The perception of painful stimuli may be quantitatively and qualitatively modified by a series of internal and external factors ${ }^{9,11}$ where these include emotional state and awareness, social, cultural and environmental aspects, the meaning of pain experiences and finally, the context in which pain occurred. The first step in the sequence of events that give rise to the sensitive phenomenon of pain is the transformation of environmental stimuli into action potentials that are transmitted to the Central Nervous System (CNS) by the peripheral sensitive fibers. ${ }^{12}$ The activity of the nociceptors is modulated by chemical substances released in high concentrations in the tissue environment due to inflammatory, traumatic and/ or ischemic processes. ${ }^{13}$ Pain is the most common symptom reported by the elderly and is present in more than $50 \%$ of their complaints; $19 \%$ of hospitalized elderly have moderate to severe pain. However, significant growth in the elderly population is expected in the next 50 years (groups more than 65 years old will grow from $7.4 \%$ to $16.4 \%$ and those older than 80 years old will triple by 2050 worldwide). ${ }^{2,8}$ In parallel with this increase in life expectation, quality of life and physical, psychological and social wellbeing is expected to be preserved at this age. Thus, pain should be identified and controlled.

In the elderly, pain is in general chronic and associated to degenerative and articular diseases, which occur in 50\% to $70 \%$ of individuals between 60 and 85 years old. Headaches and facial pains are present in $3 \%$ to $5 \%$ of this group and completely edentulous patients are very common in the general population (particularly the third age), constituting an important cause of secondary headache largely due to TMD. ${ }^{8}$

\section{Dental infection and orofacial pain}

Besides TMD, dental pain is an important cause of orofacial pain. Dental infections have an important role in the dentistry routine due to the risk of dissemination and given the severe complications that they can cause. ${ }^{14}$ The normal oral microorganism organization is very complex, and infection occurs with the imbalance between the commonly found microorganisms (which are the natural protection against throat and upper airway infections) and the pathogenic microorganisms under specific conditions. ${ }^{14}$

Such infections are generally not localized and in some circumstances affect bone tissue, muscles and mucosa spreading throughout the space of the fascias resulting in severe infection which can be extremely painful and even lead to mortality. ${ }^{7}$ The etiology of the oral septic process and the course of evolution of the infection will depend on the resistance of the organism and on the virulence of the pathogens. ${ }^{7}$

When the patient has a degree of immune compromise because of a primary pathology or a therapeutic situations (e.g. Transplants), dental infections carry higher risks due to immune suppression. Under these circumstances, patients can have higher dissemination of inflammation and infection, and more pain. It is important to bear in mind that the chemical mediators involved in periodontal inflammation are not only locally released by inflammatory cells but also by peripheral nerve endings causing neurogenic inflammation, usually diffuse and spread, which is very similar to masticatory muscle pain or atypical facial pain. ${ }^{79}$ In chronic patients with pain, periodontal disease should be investigated as a determinant factor as its treatment can improve the facial pain.

The release of bioproducts by the dental infection can activate the synthesis of prostaglandins and the release of bradykinin by plasmatic precursors. These, along with other mediators such as histamine from the mastocytes, act synergistically increasing edema through the accumulation of plasma fluid in the tissue. The inflammatory mediators excite and sensitize the peripheral nerve fibers resulting in spontaneous pain and in the increase of the pain sensation after a stimulus, characterizing hyperalgesia. The chemical mediators stimulate the release of neuropeptides by the nerve fibers. ${ }^{9}$. Recent studies demonstrate that substance $P$, the calcitonin gene related peptide (CGRP) and neurokinin A are higher in the gingival fluid in patients with irreversible pulpar pain compared to those with painless teeth, where these mediators are reduced after dental treatment. ${ }^{15-16}$ These neuropeptides are commonly found at the trigeminal ganglion ${ }^{17}$ and vary in the gingival fluid or saliva according to the presence of periodontal disease. ${ }^{18,19}$

Chronic infections are often associated to pain, especially in acutization. Among the possible causes, imbalance between the host and infection agent may be an underlying factor caused by increased virulence or weakness of the host. On the other hand, recent evidence shows that periodontal pain might occur even in chronic cases due to algogenic mediators in the tissue. ${ }^{12,16-19}$ There is also constant release of interleukins due to immune activation. ${ }^{14,20-22}$

Other diseases associated to the inflammatory process that can be worsened by dental infections are: rheumatic diseases, because of the pathogenic role of cytokines and interleukins: ${ }^{23}$ diabetes mellitus, given its association with higher prevalence of infections and the proinflammatory role of insulin; ${ }^{24}$ coronariopathies, owing to the inflammation role in vascular disease etiology,,$^{25,26}$ and also AD.

\section{Inflammatory activity and Alzheimer's disease $(A D)$}

There is evidence that inflammatory processes are relevant in the pathophysiology of $\mathrm{AD}^{27-30}$ Cytokines represent more than 50 proteins that participate in the regulation of 
growth, development and activation of the immune system and in the mediation of the inflammatory response throughout the body. ${ }^{23,24}$ Patients with AD have high levels of interleukin 1 (IL-1), interleukin 6 (IL-6), and tumoral necrosis factor (TNF) in blood serum and in extracts of brain tissue. However, the exact role of the inflammatory process in $\mathrm{AD}$ is not known. ${ }^{31-34}$

\section{Dental infections and the Alzheimer's disease (AD)}

Many recent studies have shown that patients with $\mathrm{AD}$ have higher compromise of oral health with decays, infections and teeth loss. ${ }^{30,35-39}$ Among people with dementia, the prevalence of edentulism is higher than in the general population. ${ }^{28,37,38}$ There is also a reduction in masticatory efficiency proportional to cognitive impairment ${ }^{29,40}$ and it is noteworthy that cognitive impairment in patients with $\mathrm{AD}$ may contribute to the worsening of oral hygiene thus aggravating oral infections. ${ }^{36,39,41}$

Among dental infections, periodontal disease have being demonstrated as one of the most important in terms of activation of inflammation and systemic impact. ${ }^{23}$ Periodontal disease is defined as the infection and chronic inflammation of the supporting tissues of the teeth (gingival, periodontal ligament, alveolar bone) (American Academy of Periodontology - AAP, 1999). Many forms of periodontal disease can result in systemic inflammation which is characterized by increased serum C Reactive Protein, IL-1 and IL-6. ${ }^{42}$ Akin to other systemic diseases such as diabetes mellitus, rheumatoid arthritis and coronariopathies, periodontal disease can play a role in $\mathrm{AD}$ as an underlying chronic inflammation. ${ }^{43}$ Periodontal disease can predict higher serum C Reactive Protein concentration, ${ }^{19}$ where treatment of periodontal disease can reduce its concentration ${ }^{21,23}$.

On the other hand, these inflammatory factors (IL-1, IL-6, TNF, C Reactive Protein) are also increased in the blood of patients with $\mathrm{AD}^{33,34}$ and in elderly without $\mathrm{AD}$ but with cognitive impairment, ${ }^{32}$ and thus can be a marker for risk of developing dementia. ${ }^{30}$ In addition, infection can act directly by increasing the deposits of $A \beta$ in patients with $\mathrm{AD} .^{2}$

\section{Pain relief and improvement of dementia symptoms}

Dental infections and orofacial pain can play a role in cognitive, functional and behavioral impairments in $\mathrm{AD}$ as shown by the case of an individual with $\mathrm{AD}$ who had severe orofacial pain due to TMD and after TMD treatment and pain relief showed substantial improvement in emotional (anxiety and depression) aspects, quality of life and functional activities. The pain in this case was associated with a severe chronic headache, which was diagnosed as masticatory myofascial pain secondary to TMD. ${ }^{44}$ This type of TMD is characterized by diffuse, spreading, deep pain which is often related to the adjacent areas (head and neck). When evaluating a patient with $\mathrm{AD}$, cognitive impairment represents only part of the signs and symptoms that can be affected, and this case reported an improvement in other parameters besides cognition, that contribute to dementia severity through the treatment of orofacial pain.

Dementia can impact mandibular function, ${ }^{40}$ and this might explain the development of TMD in this patient with $\mathrm{AD}$. Moreover, the pain can aggravate function, quality of life and cognition. ${ }^{11}$ It is also known that the loss of posterior teeth can contribute to TMD, ${ }^{10}$ and that $\mathrm{AD}$ can contribute to teeth loss. ${ }^{38}$ The investigation of the causes of orofacial pain is crucial in patients with dementia given the associations reviewed and observed in this case.

To conclude, many studies have shown that individuals with cognitive impairment have more dental decay, worse oral hygiene and fewer teeth. Inflammatory activation by dental infections and its systemic implications can contribute toward modulating and aggravating the neurodegenerative process that occurs in $\mathrm{AD}$. Long-term studies investigating the severity of dental infections, especially periodontal disease, along with its systemic interactions such as blood concentration of C Reactive protein and cytokines in patients with $\mathrm{AD}$ and healthy subjects should be conducted and future studies should investigate orofacial pain complaints to determine their exact participation and possible factors underlying these correlations. The role of masticatory function compromise in patients with $\mathrm{AD}$ should also be investigated.

Acknowledgements - The authors would like to thank the FAPESP (Research Support Foundation of Sao Paulo) for financial support of this study (2007/04930-1).

\section{References}

1. Gomes JCP. Pain in the elderly. In: Teixeira MJ. Manual for the general practitioner. São Paulo: Atheneu; 2006:423-435.

2. Finch CE, Morgan TE. Systemic inflammation, infection, ApoE alleles, and Alzheimer disease: a position paper. Curr Alzheimer Res 2007;4:185-189.

3. Herrera E Jr, Caramelli P, Silveira ASB, Nitrini R. Epidemiologic survey of dementia in a community-Dwelling Brazilian population. Alzheimer Disease Assoc Dis 2002;16:103-108.

4. Caixeta L. Dementia: Multidisciplinary assessment. São Paulo. Atheneu; 2006.

5. McKhann G, Drachman D, Folstein M, et al. Clinical diagnosis of Alzheimer's disease: report of the NINCDS-ADRDA work group under the auspices of department of health and human services task force on Alzheimer's disease. Neurology 1984;34:939-944. 
6. Folstein MF, Folstein SE, McHugh PR. Mini-mental state: a practical method for grading the cognitive state of patients for the clinician. J Psych Res 1975;12:189-198.

7. Pfeffer RI, Kurosaki TT, Harrah CH Jr, et al. Measurement of functional activities in older adults in the community. J Gerontol 1982;37:323-329.

8. IASP: International Association for the study of pain subcommittee on taxonomy: classification of chronic pain, description of chronic pain syndromes and definitions of pain terms. Pain 2006;3:S1-S225.

9. Melzack R, Wall PD. Pain mechanisms: a new theory. Science 1965;50:971-979.

10. Lipton JA, Ship JA, Larach-Robinson D. Estimated prevalence and distribution of reported orofacial pain in the United States. J Am Dent Assoc 1993;124:115-121.

11. Seminowicz DA, Davis KD. A re-examination of pain-cognition interactions: implications for neuroimaging. Pain 2007; 130:8-13.

12. Sessle BJ. Acute and chronic craniofacial pain: brainstem mechanisms of nociceptive transmission and neuroplasticity, and their clinical correlates. Crit Rev Oral Biol Med 2000;11: 57-91.

13. Rubin S, Chawla S. Chronic pain in the dental patient. Dent Clin North Am 1999;43:421-433.

14. Van Oijen M, de Maat MP, Kardys I, et al. Polymorphisms and haplotypes in the $\mathrm{C}$-reactive protein gene and risk of dementia. Neurobiol Aging 2007;28:1361-1366.

15. Dimopoulos N, Piperi C, Salonicioti A, et al. Indices of lowgrade chronic inflammation correlate with early cognitive deterioration in an elderly Greek population. Neurosci Lett 2006;398:118-123.

16. Griffin WS. Inflammation and neurodegenerative diseases. American J Clin Nut 2006; 83:470S-474S.

17. Haan MN, Aiello AE, West NA, Jagust WJ. C-reactive protein and rate of dementia in carriers and non carriers of Apolipoprotein APOE4 genotype. Neurobiol Aging 2008;29: 1774-1782.

18. Mrak RE, Griffin WS. Interleukin-1, neuroinflammation, and Alzheimer's disease. Neurobiol Aging 2001;22:903-908.

19. Rogers J, Lue LF. Microglial chemotaxis, activation, and phagocytosis of amyloid beta-peptide as linked phenomena in Alzheimer's disease. Neurochem Int 2001;39:333-340.

20. Schmidt R, Schmidt H, Curb JD, Masaki K, White LR, Launer LJ. Early inflammation and dementia: a 25-year follow-up of the Honolulu-Asia Aging Study. Ann Neurol 2002;52:168-174.

21. Tan ZS, Beiser AS, Vasan RS, et al. Inflammatory markers and the risk of Alzheimer disease: the Framingham Study. Neurology 2007;68:1902-1908.

22. Lalla E, Kaplan S, Yang J, Roth GA, Papapanou PN, Greenberg S. Effects of periodontal therapy on serum C-reactive protein, sE-selectin, and tumor necrosis factor-alpha secretion by pe- ripheral blood-derived macrophages in diabetes: a pilot study. J Periodont Res 2007;42:274-282.

23. Nilsson M, Kopp S. Gingivitis and periodontitis are related to repeated high levels of circulating tumor necrosis factor-alpha in patients with rheumatoid arthritis. J Periodontol 2008;79: 1689-1696.

24. Loos BG. Systemic effects of periodontitis. Ann R Aust Coll Dent Surg 2006;18:27-29.

25. Nóbrega JC, Siqueira SR, Siqueira JT, Teixeira MJ. Differential diagnosis in atypical facial pain: a clinical study. Arq Neuropsiquiatr 2007;65 256-261.

26. Awawdeh LA, Lundy FT, Linden GJ, Shaw C, Kennedy JG, Lamey PJ. Quantitative analysis of substance P, neurokinin A and calcitonin gene-related peptide in gingival crevicular fluid associated with painful human teeth. Eur J Oral Sci 2002;110: 185-191.

27. Ide M, Jagdev D, Coward PY, Crook M, Barclay GR, Wilson RF. The short-term effects of treatment of chronic periodontitis on circulating levels of endotoxin, C-reactive protein, tumor necrosis factor-alpha, and interleukin-6. J Periodontol 2004;75:420-428.

28. Ioannidou E, Malekzadeh T, Dongari-Bagtzoglou A. Effect of periodontal treatment on serum C-reactive protein levels: a systematic review and meta-analysis. J Periodontol 2006;77: 1635-1642.

29. Beck JD, Offenbacher S. Systemic effects of periodontitis: epidemiology of periodontal disease and cardiovascular disease. J Periodontol 2005;76(Suppl):2089-2100.

30. Pussinen PJ, Jousilahti P, Alfthan G, Palosuo T, Asikainen S, Salomaa V. Antibodies to periodontal pathogens are associated with coronary heart disease. Arteriosclerosis Thrombosis Vasc Biol 2003;23:1250-1254.

31. Gazelius B, Edwall B, Olgart L, Lundberg JM, Hokfelt T, Fisher JA. Vasodilatory effects and coexistence of calcitonin generelated peptide (CGRP) and substance $\mathrm{P}$ in sensory nerves of cat dental pulp. Acta Physiol Scand 1987;130:33-40.

32. Linden GJ, McKinnel J Shaw FT. Substance P and neurokinin A in gingival crevicular fluid in periodontal health and disease. J Clin Periodontol 1997;24:799-803.

33. Lundy FT, Shaw C, McKinell J, Lamey P-J, Linden GJ. Calcitonin gene-related peptide in gingival crevicular fluid in periodontal health and disease. J Clin Periodontol 1999;26:212-216.

34. Blum A, Front E, Peleg A. Periodontal care may improve systemic inflammation. Clin Invest Med 2007;30:E114-117.

35. Avlund K, Holm-Pedersen P, Morse DE, Viitanen M, Winblad B. Tooth loss and caries prevalence in very old Swedish people: the relationship to cognitive function and functional ability. Gerodontol 2004;21:17-26.

36. Henriksen BM, Engedal K, Axéll T. Cognitive impairment is associated with poor oral health in individuals in long-term care. Oral Health Prevent Dent 2005;3:203-207. 
37. Newton JP. Dementia, oral health and the failing dentition. Gerodontol 2007;24:65-66.

38. Stein PS, Desrosiers M, Donegan SJ, Yepes JF, Kryscio RJ. Tooth loss, dementia and neuropathology in the Nun study. J Am Dent Assoc 2007;138:1314-1322.

39. Syrjälä AM, Ylöstalo P, Sulkava R, Knuuttila M. Relationship between cognitive impairment and oral health: results of the Health 2000 Health Examination Survey in Finland. Acta Odontologica Scand 2007;65:103-108.

40. Miura H, Yamasaki K, Kariyasu M, Miura K, Sumi Y. Relationship between cognitive function and mastication in elderly females. J Oral Rehab 2003;30:808-811.

41. Padilha DM, Hugo FN, Hilgert JB, Dal Moro RG. Hand func- tion and oral hygiene in older institutionalized Brazilians. J Am Ger Soc 2007;55(90):1333-1338.

42. Rogers J. The inflammatory response in Alzheimer's disease. J Periodontol. 2008;79(8 Suppl):1535-1543.

43. Kamer AR, Craig RG, Dasanayake AP, Brys M, Sobanska LG, Leon MJ. Inflammation and Alzheimer's disease: possible role of periodontal diseases. Alz Dementia 2008;4:242-250.

44. Dworkin SF, LeResche L. Research diagnostic criteria for temporomandibular disorders: review, criteria, examinations and specifications, critique. J Craniomand Dis 1992;6:301-355.

45. Slade GD. Derivation and validation of a short-form oral health impact profile. Community Dent Oral Epidemiol 1997; 25:284-290. 